\title{
Worlds of awards
}

The Oscars, BAFTAs, the Golden Globe Awards, the Palm d'Or (the Cannes Film Festival), the Sundance Film Festival Awards, New York Film Critics Circle Awards - and literally hundreds and hundreds of national awards recognise and idolise the stars of the movie, stage and television worlds. In sport, the Olympic Games, the FIFA and CAF awards, the Laureus, the International Sport Award, the PGA, the Formula 1 Grand Prix, World Swimming Masters Championships and the Tennis Grand Slams - also amongst hundreds of others - recognise and venerate (and sell to an audience) the world's top sportspeople. And in both arenas the stars and near stars are all rewarded with handsome earnings.

Yet in the world of science there are just three or four high-level equivalents: the Nobel Prizes; the Holberg Prize, the Fields Medals and the Abel Prize. Of course, there are also innumerable national and organisational awards for scientists. In South Africa, the Harry Oppenheimer Fellowships Award, the Gold Medal of the Academy of Science of South Africa (ASSAf), the Alan Paton Award and the six National Orders at their various levels including those made to high achievers other than scientists of course - are amongst them. Internationally, however, it is really just the Nobel and the Holberg Prizes, and possibly the Fields Medals, that command international interest and (at times) fame, although rarely wealth.

In this issue of the SAJS, however, we foreground and celebrate awards and honours made to South African scientists who have gained fame locally and internationally for the major contributions they have made to science in their fields, and whose work has changed the lives of thousands of people around the world.

Altogether, there are 55 scientists whose honours are highlighted in this issue. Two have gained recognition from possibly surprising sources: Prof. Glenda Gray and Dr Stephanie Fanucchi. Prof. Gray, Chief Executive Officer and President of the Medical Research Council, has been recognised by Time magazine as one of the top 100 most influential people in the world for 2017. Dr Fanucchi, a cell biologist, is a senior researcher at the Council for Scientific and Industrial Research and was awarded one of just 15 L'Oréal/UNESCO International Rising Talent Awards for 2017. Dr Fanucchi was also a finalist for the 2016/2017 TW Kambule-NSTF Award for Emerging Researchers. These leading women scientists and their work are the subjects of two News and Views items in this issue.

The other 53 scientists have been honoured in a book published by ASSAf - called simply and appropriately Legends of South African Science. ASSAf set a very strict condition to be met for anyone to be included in the book: 'legends' had to have been a recipient of at least one of South Africa's top awards - the ASSAf Science-for-Society Gold
Medal, National Orders of Mapungubwe or Baobab bestowed by the President, or the Harry Oppenheimer Fellowship. The book was launched on 25 July 2017, and is reviewed in this issue. Without pre-empting the review there is, however, a notable observation that emerges from the book as far as awards are concerned.

This observation is the amazing range and number of awards (over and above the requirement by ASSAf) that the 53 legends have received and named as their three most valued awards. These 53 scientists have listed amongst them 104 additional awards. If their other, unlisted awards and duplicates, were to be included, the number would almost certainly more than double. As a simple example, both Arthur Chaskalson and Friedel Sellschop were awarded honorary doctorates by five universities - none of which are listed in their top three awards.

Recently, the National Science and Technology Forum (NSTF) named the winners in its nine categories of excellence in a wide range of fields - all of which have both scientific and social merit. The winner in the category of 'Over a lifetime achievement by an individual' was SAJS Associate Editor Prof. Nicolas Beukes of the University of Johannesburg. We hope to carry Commentaries or Reviews from some of the winners over the next six issues of the Journal.

Why should awards and recognition be important enough to highlight in this issue of SAJS - through the Leader, two News and Views items and a Book Review? The reasons for having and for recognising the legends of science are innumerable.

We all need entertainment in our lives - whether it be through watching films or plays, listening to a Rachmaninov piano concerto, watching a nail-biting football match or the Wimbledon finals, or reading a great novel. Palaeoanthropological discoveries have revealed that recreation has been a part of human life for thousands of years - whether in the form of music, dancing, storytelling or jewellery making.

But we also need new knowledge, for its own sake and for its application - jobs, economic and social growth, better health and safer lives - and for the ability to keep doing better as the challenges we face grow greater. Science is the source and foundation of what makes it possible to meet all of those needs. It makes sense, then, to recognise, reward and value the people who make that happen. Science (and its applications) are frequently taken for granted rather than being understood as fundamental and essential parts of ordinary lives - our own and others. But it needs to be so understood - if we cannot recognise and respect our own community of scientists, how might we ever spread the word more widely? 